\title{
Penyuluhan tentang Pemanfaatan Media Digital Marketing dalam Penyampaian Informasi sebagai Wujud Pelayanan Prima pada Anggota Yayasan Pundi Rakyat Jakarta Pusat
}

\section{Susilowati1, Gan Gan Giantika², Azwar Munanjar³, Ichsan Widi Utomo4}

\author{
1,2,3,4Fakultas Komunikasi dan Bahasa, Universitas Bina Sarana Informatika, Indonesia \\ *e-mail: susilowati.ssi@bsi.ac.id ${ }^{1}$, gan.ggt@bsi.ac.id² ${ }^{2}$, azwar.azw@bsi.ac.id ${ }^{3}$, ichsan.iwu@bsi.ac.id ${ }^{4}$
}

\begin{abstract}
Abstrak
Sebuah organisasi non profit yang mempunyai orientasi tidak untuk memperoleh keuntungan juga membutuhkan suatu kecepatan di dalam melakukan pelayanan yang sangat baik pada para pemangku kepentingan di dalam organisasi tersebut. Sehingga sangat dirasakan tepat untuk mengadakan suatu penyuluhan pada Yayasan Pundi Rakyat dalam menyampaikan informasi semua kegiatan yang dilakukan yayasan tersebut agar dapat diketahui mayarakat ataupun mitra mereka. Pelaksanaan dalam pengabdian masyarakat ini dilakukan dengan tahapan Persiapan, Pelaksanaan Kegiatan, dan memonitoring serta mengevaluasi dan tahapan terakhir adalah pelaksanaan kegiatannya. Pelaksanaan dilakukan secara online menggunakan Zoom Cloud Meeting. Kesimpulan yang diperoleh dari Pelaksanaan kegiatan pengabdian masyarakat adalah dengan penyuluhan ini dapat dijadikan sebagai edukasi dalam memberikan manfaat yang baik untuk anggota Yayasan Pundi Rakyat dan sesuai dengan apa yang dibutuhkan oleh mereka untuk melakukan penyebaran informasi kegiatan yang dilakukan oleh Yayasan Pundi Rakyat agar dapat diketahui oleh masyarakat atapun mitra mereka dalam penyumbang dana atau donatur dan juga calon dari para donatur baru sebagai wujud pelayanan yang prima dengan menggunakan memanfaatkan media digital marketing.
\end{abstract}

Kata Kunci: Media Digital Marketing, Pelayanan Prima

\begin{abstract}
A non-profit organization that has a non-profit orientation also needs a speed in providing excellent service to stakeholders within the organization. So it is felt right to hold an outreach to the Pundi Rakyat Foundation in conveying information on all activities carried out by the foundation so that the community or their partners can know. Implementation in community service is carried out with the stages of Preparation, Implementation of Activities, and monitoring and evaluating and the last stage is the implementation of activities. The implementation is carried out online using Zoom Cloud Meeting. The conclusion obtained from the implementation of community service activities is that this counseling can be used as education in providing good benefits for members of the Pundi Rakyat Foundation and in accordance with what is needed by them to disseminate information on activities carried out by the Pundi Rakyat Foundation so that it can be known by the public. or their partners in donating funds or donors and also prospective new donors as a form of excellent service by using digital marketing media.
\end{abstract}

Keywords: Digital Marketing Media, Excellent Service

\section{PENDAHULUAN}

Perkembangan teknologi informasi yang sangat pesat nantinya akan memberikan banyak dampak positif dalam persaingan usaha. Teknologi informasi dan komunikasi mengalami kemajuannya saat ini sudah mendapat pengakuan dan juga dirasakan telah memudahkan untuk kehidupan manusia. Penyebaran informasi didorong oleh adanya perkembangan teknologi dalam bentuk media digital dengan sangat cepat. Hal ini dikarenakan dapat dengan mudah menyebarkan informasi ke segala penjuru dunia dengan berbagai aspek kehidupan yang selalu berkembang. Transformasi digital menjadikan sebuah cara dalam adaptasi dengan mempercepat dalam pelaksanaan informasi mengenai perusahaan ataupun pemerintah kepada publiknya Sebagai langkah yang bertujuan untuk melakukan pelayanan yang mempuanyai kualitas yang baik, cepat dan tidak sulit dan mudah dijangkau serta menjadi sebuah pengukuran pada masyarakat khususnya pada saat pandemic saat ini. Pemakaian digital 
marketing yaitu sebagai langkah untuk memudahkan pemahaman mengenai apa yang menjadi tujuan dari komunikasi temtang digital marketing, maka Morissan (Morisan, 2010), yaitu:

1. Menyebarkan berbagai informasi

Satu diantara tujuan digital marketing yaitu sebagai penyebaran informasi-informasi dengan cara utuh dan lengkap juga dengan cara yang dalam tentang suatu produk dari sebuah organisasi. Organisasi dalam penggunaan digital marketing mempunyai sebuah kesempatan yang besar untuk memperoleh komsumen.Penggunaan digital marketing secara singkanya adalah sebuah media yang sangat cocok untuk penyebaran informasi kepada masyarakat.

2. Mewujudkan akan pengakuan

Sebuah organisasi dengan ukuran kecil atau belum mempunyai budget dengan batasan yang kuat pada saat melaksanakan sebuah pemasaran, maka digital marketing mewujudkan akan pengakuan dengan cara yang efektif dibandingkan media lain yang dilakukan secara tradisional, maka digital marketing dapat dikatakan memiliki manfaat sebagai media yang dapat membentuk pengakuan akan organisasi dan perusahaan baik jasa ataupun produknya.

3. Tujuan untuk penelitian

Selain ditujukan untuk media dalam memasarkan produk perusahaan tetapi juga sebagai alat guna melakukan riset pasar juga melakukan pengumpulan informasi bagi para competitor dan pelanggan sebagai target sasaran.

4. Membentuk Opini

Organisasi yang memanfaatkan media digital sebagai media yang dapat membentuk opini masyarakat berkenaan dengan citra organisasi di mata masyarakatnya.

5. Uji coba Produk

Sebuah Organisasi dalam penggunaan digital marketing guna melaksanakan ujicoba produknya, maka perusahaan dapat juga membuat sebuah kampanye penawaran sebuah kupon elektronik pada konsumen sasaran atau konsumen dapat melakukan dorongan supaya berkeinginan untuk melakukan percobaan produk mereka.

6. Melakukan peningkatan pelayanan

Organisasi banyak yang sudah merasakan pemanfaatan dalam menggunakan digital marketing. Digital marketing tidak hanya menyuguhkan informasi dengan lengkap, tetapi juga dapat memberikan jawaban berbagai pertanyaan dan juga keluhan dari pelanggan.

7. Memberikan peningkatan distribusi

Digital marketing ialah media yang memiliki berbagai cara untuk melakukan pemasaran yang dijalankan organisasi, dimana dengan cara yang terdapat pada perusahaan tersebut mampu bekerjasama untuk melakukan promosi serta memberikan penampilan produknya, salah satu tools tersebut adalah website.

Sesuai dengan pernyataan Morisan diatas, maka dapat disimpulkan bahwa penggunaan media digital marketing ini merupakan sebuah kegiatan komunikasi yang dilakukan perusahaan dalam melakukan berbagai kegiatan komunikasi dalam menyebarkan informasi, serta meningkatkan pelayanan dari suatu perusahaan khususnya keterkaitan dengan kepuasan dari pelanggan dan menanggapi keluhan dari pelanggan yang merupakan bagian dari pelayanan prima (service of excellence) dalam sebuah perusahaan.

Seperti yang diungkapkan oleh Pratomo dan Pratomo \& Shaff (2000) mengatakan bahwa pelayanan prima merupakan suatu rasa pedulu pada pelanggannya, sehingga pelayanan prima pada umunya yaitu rasa pedulinya sebuah organisasi yang mempunyai orientasi keuntungan (profit oriented) maupun orgaisasi yang mempunyai orientasi social (non profit) pada pelanggan dengan menunjukkan suatu perilaku, perhatian, serta aksi yang jelas, sehingga memberikan kenayamanan pada pelanggannya atas pelayanan prima yang telah dilakukan.

Pada kalangan masyarakat terdapat bentuk organisasi salah satunya adalah lembaga atau organisasi nirlaba atau non profit. Organisasi atau lebaga jenis ini merupakan salah satu diantara komponen pada sebuah masyarakat yang mempunyai peran penting sejak era reformasi. Pada kehidupan saat ini makin banyak terlibatnya organisasi-organisasi non profit. Keberadaan dari organisasi non profit ini disebabkan dengan adanya manusia sebagai makhluk social yang mempnyai kecendrungan dalam hidupnya untuk melakukan hubungan dengan 
masyarakat dan melakukan pengorgasisasian dalam suatu kegiatannya untuk meraih apa yang dituju, namun dikarenakan mempunyai sebuah keterbatasan dalam kemampuannya maka mereka dapat mencapai tujuannya dengan melakukan kerjasama.

Sebagai organisasi non profit, maka tujuan yang diutamakan pada organisasi tersebut bukanlah laba. Yang sangat diutamakan pada organisasi non profit adalah memiliki manfaat untuk masyarakat banyak. Karakteristik dari sebuah organisasi non profit menurut Mohamad Mahsun (2009), ialah: 1) Sumber daya entitas yang bersumber dari pemberi sumbangan (donator) tanpa berharap laba ataupun kegunaan dalam segi atau bidang ekonomi selaras besaran potensi yang sudah dipersembahkan, 2) Mendapatkan hasil berupa produk ataupun jasa yang mempunyai tujuan tidak untuk memperoleh laba, bila suatu entitas memperoleh laba, sehingga hasil yang diperoleh akan dibagikan lagi pada pendiri-pendiri atau yang memiliki entitas, 3) Tidak memiliki kepemilikan layaknya organisasi usaha, maka kepemilikan pada organisasi non-profit tidak bisa untuk dilakukan penjualan, dipindahkan, atau dilakukan penebusan kembali (Wisataone, 2018).

Sedangkan organisasi non profit menurut Pahala Nainggolan dalam (Anggita, Yunita, Rosalina, \& Fahria, 2018) bahwa organisasi non profit adalah sebuah organisasi atau sekumpulan orang-orang yang mempunyai tujuan tertentu serta melakukan kerjasama dalam meraih apa yang menjadi tujuannya tersebut, pada saat melaksanakan sebuah kegiatan yang dilakukannya, mereka mempunyai orientasi tidak untuk menumpukkan keuntungan.

Sekalipun di dalam organisasi yang mempunyai orientasi tidak untuk memperoleh keuntungan, akan tetapi di dalam organisasi non profit juga membutuhkan suatu kecepatan di dalam melakukan pelayanan yang sangat baik pada para pemangku kepentingan di dalam organisasi tersebut. Sehingga organisasi terus berupaya untuk melakukan pemasaran dengan menggunakan digital organisasi non profit guna mejaga suatu hubungan, memperoleh donasi yang tetap, serta menjaga suatu image di mata masyarakat. Tidak memerlukan dana dalam membentuk tim dalam pemasaran secara special maka pemasaran dengan digital bia menjadi pertimbangan oleh organisasi non profit (Jakartaurbanhosting.com, 2019).

Pelayanan Prima menurut Atep Adya Barata (Barata, 2017) menyatakan bahwa: "Rasa peduli konsumen dengan melakukan pemberian sebuah layanan yang sangat baik guna memberkan fasilitas suatu langkah yang mudah dalam memenuhi kebutuhan dan memperoleh kepuasannya, supoaya para konsumen akan selalu setia pada perusahaan ataupun organisasi". Pada definisi pelayanan prima terdapat hal yang sangat utama tercakup kedalam tiga hal yang mendasar, yaitu: 1) Sikap untuk mendekati dan peduli dengan konsumennya, 2) Usaha untuk membaerikan pelayanan dengan menggunakan media sebagai cara untuk promosi dengan cara online telah banyak dipasarkan produk dengan efektif. Akan tetapi memerlukan strategi yang dikhusukan untuk mendapatkan daya tarik calon pelanggannya. Promosi dengan cara online bisa dilaksanakan dengan cara tanpa membayar ataupun dengan melakukan pembayaran. 3) Terdapat suatu tujuan guna meberikan kepuasan pada pelanggan dengan mengacu pada standar dari pelayanan tertentu. Terdapat beberapa media yang dapat menjadikan pilihan dari perusahaan untuk dapat digunakan sebagai dukungan dari sebuah cara promosi pada masa digital oleh para pelaku usaha, yaitu:

1. Blogging

Blogging didalamnya terlibat dalam penulisan serta menerbitkan konten dengan cara online dan topik yang sesuai dengan usahanya (Bakti.id, 2021).

\section{Media Sosial Marketing}

Banyaknya pelanggan yang memakai media social disetiap harinya dengan tujuan untuk komunikasi, mendapatkan informasi yang terdapat pada belahan dunia, termasuk juga untuk mencari pekerjaan. Media Promosi Facebook, dimana dengan hadirnya Facebook dapat digunakan sebagai media online pada saat ini yang cukup efektif sebagai cara untuk mempromosikan dan juga memasarkan sebuah produk, sedangkan dengan Instagram termasuk media social yang terbanyak digunakan Tidak sedikit pemilik usaha yang mengawali usahanya dengan menggunakan online shop dalam Instagram, hal ini dikarenakan Instagram saat ini tekah banyak mempunyai fitur yang dapat digunakan untuk melakukan promosi juga melakukan interaksi dengan konsumen (Bakti.id, 2021). 


\section{Email Marketing}

Email marketing dapat dinyatakan masih mempunyai kemampuan yang efektif sebagai langkah dalam mempromosikan secara online dan dapat menjangkau konsumen yang banyak. Email marketing dapat digunakan untuk menyebarkan berbagai informasi akan perkenalan dari produk baru, melakukan penawaran yang paling baru, serta dibatasi dengan mencantumkan diskon (Bakti.id, 2021).

Sedangkan Email marketing mempunyai enam jenis yang bisa dipakai oleh pelaku usaha (Beon, 2016), yaitu:

a. Newsletter

Jenis dari email ini mempunyai tiga keutamaannya, yaitu: 1) terdapatnya pesan yang informatif, maka dapat menjadikan email ini mempunyai penilaian yang baik dari pelanggan, 2) mampu menjadikan seseorang untuk dapat melihat website ataupun blog took online dari sebuah perusahaan yang terdapat pada link newsletter yang sudah dibuat., 3) perusahaan dapat menampilkan informasi yang baru tentang usaha yang digelutinya tersebut, misalnya memberikan potongan harga, harga promosi, dan sebagainya.

b. Digest Email

Digest Email yaitu email marketing yang secara langsung dapat dihasikan dari mailing list elektronik, dan dengan email ini pula dapat ditentukan periode dari email itu sendiri dalam penggunaannya.

c. Email Khusus

Email marketing jenis ini terdapat aneka ragam, diantaranya adalah email yang memang diciptakan oleh pelaku usaha itu sendiri, yang dimaksudkan emailini berdiri sendiri serta terkandung didalamnya hanya satu informasi juga pada umumnya menggunakan alamat email yang berlainan.

d. Email Follow-up

Email jenis ini yaitu merupakan satu rangkaian email yang telah dikirimkan kepada pelangganya dengan berupa sebuah konten yang mempunyai informasi yang baik, serta mempunyai manfaat guna berjaga-jaga supaya konsumen dari email perusahaan.

e. Email Sponsorship

Email jenis ini dapat diujicoba oleh organisasi saat memulai untuk terjangkaunya masyarakat secara luas dan baru juga organisasi berusaha agar memperoleh calon konsumen yang baru. Saat perusahaan akan menggunakan email sponsorship ini maka diharuskan perusahaan tersebut melakukan pembayaran supaya email dapat diinput pada salinan newsletter vendor yang lainnya, dan perusahaanpun dapat menentukan pilihan untuk ikut pada vendor yang mempunyai banyak konsumennya yang mempunyai potensi dan mempunyai pengaruh yang kuat untuk usahanya tersebut kedepannya.

f. Email Transaksional

Email Transaksional ini adalah suatu pesan yang akan hadir setelah diakibatkan oleh tindakan yang sudah dipilih dan mempunyai kemungkinan untuk diselesaikan tindakan tersebut misalnya dengan melakukan sebuah transaksi.

4. Iklan melalui internet pada situs Website

Iklan melalui internet pada situs Website atau biasa disebut dengan Pay-per-click merupakan iklan yang hadir pada bagian diatas halaman pada mesin pencarian. Media ini dijadikan sebagai satu diantara yang bisa menolong usaha dengan menaikkan visibilitas secara online. Kata kunci yang tepat dengan konten yang akan dilakukan pencarian mejadi pemanfaatan dalam iklan ini. Saat orang lain akan mencoba untuk mencari dengan memakai kata kunci itu di Google, maka akan didapat iklan yang terletak di atas bagian suatu halaman (Bakti.id, 2021).

\section{Content Marketing}

Kini, content marketing merupakan media untuk mempromosikan sebuah produk yang menjadi andalan, karena pada media promosi ini dapat menyuguhkan sebuah konten yang sesuai dengan pasar sasaran. Konten ini dapat berbentuk sebuah artikel, video, infografis, dan lain sebagainya. Pada konten tersebut mempunyai call to action untuk 
mengarah pada laman dari organisasi tersebut atau marketplace guna melaksanakan pemesanan.

6. Media Audio dan Visual

Media promosi menjadi bertambah luas, dan juga memasuki ke bidang lainnya. Organisasi yang mempunyai dana yang besar akan mampu untuk berinvestasi pada podcast, film, ataupun video digital dalam media promosinya.

7. Teknik mengoptimalkan website

Teknik dalam melakukan optimalisasi dari website agar menperoleh peringkat yang tinggi si google dinamakan Search Engine Optimization (SEO) ini mampu untuk menjadikan laman usaha atau artikel dari orang lain menuju suatu teratas dalam pencarian pada masa yang cepat, karena SEO dapat memberikan hal yang optimalkan situs juga artikel namun dengan banyaknya organik. Seperti pelaku usaha akan membuat sebuah artikel pada blog dari organisasi dengan memberikan sisipan berberapa dari kata kunci SEO.

8. Influencer

Dengan hadirnya influencer atau pelaku yang dapat mendengungkan sebuah pesan mempunyai kesamaan dalan hadirnya media social. Mereka tidak hanya melakukan review dari alat kecantikan, rumah makan, ataupun produk dari gaya hidup lainnya. Pendengung pun dapat difungsikan sebagai media promosi.(Niken, 2020)

Usaha yang dilaksanakan supaya dengan adanya media digital marketing mampu untuk dipahami dan diketahui dengan luas dan cakap oleh berbagai usaha, lembaga, organisasai ataupun dalam bentuk yayasan. Hal ini bisa dilakukan dengan berbagai cara, khusunya dengan memberikan sebuah penyuluhan tentang pemanfaatan media digital marketing dalam penyampaian informasi sebagai wujud pelayanan prima pada sebuah organisasi non profit seperti Yayasan Peduli Rakyat. Maka dosen dari Fakultas Komunikasi dan Bahasa program studi Penyiaran Universitas Bina Sarana Informatika dengan dibantu beberapa mahasiswa pada program studi Penyiaran melaksanakan kegiatan pengabdian masyarakat dengan tema "Penyuluhan Tentang Pemanfaatan Media Digital Marketing Dalam Penyampaian Informasi Sebagai Wujud Pelayanan Prima".

Yayasan Pundi Rakyat berlokasi di Jl. Taruna VIII No 6C RT. 004 RW 01 Kelurahan Serdang, Kecamatan Kemayoran Jakarta Pusat 10650. Terbentuknya Yayasan Pundi Rakyat dengan adanya kesenjangan sosial di Kelurahan Serdang. Generasi muda bernama Yadhy Cahyady pun menggagas untuk menjembatani pada tahun 2014. Saat itu, yang dilakukan adalah menjalankan program Koin (Kolam Infak), dengan mengajak warga agar menyisihkan rejekinya setiap hari kemudian hasilnya dibagikan kepada masyarakat yang membutuhkan. Serta berbagai program seperti Cerdik, Permata, Pahala, dan lainnya.

Visi dari Yayasan Pundi Rakyat, yaitu untuk menjadi lembaga kesejahteraan sosial yang profesional, amanah, dan sinergi sebagai peningkatan taraf hidup dan kesejahteraan masyarakat, dan juga mempunyai misi; 1) Membangun jejaring kemitraan. 2) Mengajak partisipasi peran serta mayarakat pada pelaksanaan dari kegiatan social kemasyarakatan, 3) Menyalurkan bantuan sosial kepada masyarakat khususnya anak terlantar, lanjut usia, dan keluarga miskin. 4) Melakukan pembinaan dan pemberdayaan lingkungan kemasyarakatan. 5) Memberikan peningkatan dalam kualitas Sumber Daya Manusia (SDM) pelaksana kegiatan.

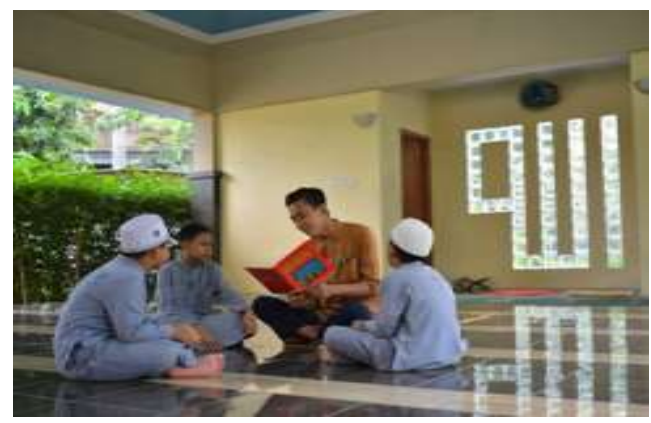

Gambar 1. Kegiatan Sosial Kemasyarakatan Dalam Meningkatkan kualitas Sumber Daya Manusia (SDM) 
Yayasan Pundi Rakyat juga melakukan pendataan terhadap anggotanya yang membutuhkan peningkatan keterampilan sesuai keminatan anak dan mempunyai tujuan; 1) Meningkatkan taraf hidup dan kesejahteraan masyarakat khususnya anak terlantar, lanjut usia, dan keluarga miskin. 2) Memberikan pengarahan, pembinaan, dan bimbingan kepada anak terlantar, lanjut usia, dan keluarga miskin agar hidup mandiri di tengah-tengah masyarakat. 3) Memberikan bantuan kepada anak terlantar, lanjut usia, dan keluarga miskin berupa dana tunai, beras, makanan dan kebutuhan sehari-hari lainnya.

Yayasan Pundi Rakyat memiliki latar belakang pendidikan yang tidak sama dan heterogennya latar belakang anggota Yayasan Pundi Rakyat dapat meningkatkan kualitas Sumber Daya Manusia (SDM) sesuai ciri khas dan kemampuan masing-masing anggota terutama dalam bidang tentang pemanfaatan media digital marketing dalam penyampaian informasi sebagai wujud pelayanan prima pada masyarakat, maka memerlukan suatu pengetahuan akan media digital marketing pada era digital saati ini. Pengetahuan yang diberikan dalam bentuk penyuluhan tentang pemanfaatan media digital marketing dalam penyampaian informasi sebagai wujud pelayanan prima.

Dengan pelaksanaan kegiatan pengabdian masyarakat ini berupa penyuluhan ini diharapkan agar peserta dari anggota Yayasan Pundi Rakyat mampu untuk memperoleh pengetahuan serta memperoleh suatu pemahaman yang baru dengan memanfaatkan media digital marketing untuk memberikan informasi atas jasa atau kegiatan-kegiatan kemasyarakatan selama ini kepada masyarakat atau mitra dari Yayasan Pundi Rakyat. Hal ini sebagai wujud pelayanan prima yang dapat mereka lakukan pada masyarakat atau mitra mereka untuk mendapatkan image yang baik pada pelayanan yang mereka lakukan dengan memanfaatkan media digital yang berbasis denga internet.

Pada pelaksanaan Pengabdian Masyarakat saat ini menyesuaikan dengan kondisi yang terjadi pada masa era Pandemi COVID-19 dan tetap mengikuti instruksi pemerintah agar menerapkan pembatasan jarak fisik sebagai langkah preventif dalam mencegah penularan virus Corona, sehingga dalam penyelenggaraanya mengggunakan sistem online atau menggunakan zoom conference.

\section{METODE}

Metode yang dilakukan di dalam melaksanakan kegiatan penyuluhan guna menyelesaikan persoalan yang terjadi pada Yayasan Pundi Rakyat ini yaitu;

\subsection{Tahap Persiapan}

Pada tahapan ini dimaksudkan guna mengetahui setiap masalah yang dihadapi oleh Yayasa Pundi Rakyat serta pengajuan dalam ijin dalam melaksanakan kegiatan-kegiatan di dalam pelatihan di Yayasan tersebut. Selanjutnya melakukan persiapan untuk penyuluhan dengan membuat materi penyuluhan tentang pemanfaatan media digital marketing dalam penyampaian informasi sebagai wujud pelayanan prima, membuat soal tes serta kuesioner sebagai cara untuk mengetahui aksi dan respon peserta pengabdian masyarakat

\subsection{Tahap Pelaksanaan}

Tahapan pertama yaitu penyuluhan dan pemaparan materi tentang pemanfaatan media digital marketing dalam penyampaian informasi sebagai wujud pelayanan prima pada anggota yayasan pundi rakyat. Pemanfaatan media digital marketing sangat penting dalam meningkatkan pengetahuan dan pemahaman terutama untuk memanfaatkan teknologi informasi dan komunikasi serta meningkatkan Sumber Daya Manusia (SDM).

Tahap kedua yaitu pelatihan, pendampingan, dan simulasi penyusunan materi penyuluhan tentang pemanfaatan media digital marketing dalam penyampaian informasi sebagai wujud pelayanan prima pada anggota yayasan pundi rakyat. 


\subsection{Tahapan dalam Memonitoring serta Mengevaluasi.}

Tahapan di dalam memonitoring dan juga mengevaluasi ini dilakukan dengan memberikan beberapa tes dan soal yang dapat diisi oleh pihak mitra dan juga peserta sebagai pengukuran besaran dari peningkatan kemampuan Mitra setelah pelaksanaan penyuluhan. Pihak mitra juga diminta untuk melakukan melakukan pengisian kuesioner agar dapat mengetahui seberapa besar respon dari peserta penyuluhan.

\subsection{Pelaksanaan}

Kegiatan Pengabdian Masyarakat ini akan dilaksanakan pada hari Sabtu tanggal 23 Oktober 2021 dimulai pukul 09.00 WIB sampai dengan pukul 12.00 WIB yang berlokasi pada Yayasan Pundi Rakyat berlokasi di Jl. Taruna VIII No 6C RT. 004 RW 01 Kelurahan Serdang, Kecamatan Kemayoran Jakarta Pusat 10650 dengan metode yang digunakan secara online yaitu menggunakan media video Conference Zoom Cloud Meeting dengan dihadiri 10 orang Peserta terdiri dari anggota Yayasan Pundi Rakyat. Pengabdian kepada masyarakat yang diberikan berupa Penyuluhan tentang pemanfaatan media digital marketing dalam penyampaian informasi sebagai wujud pelayanan prima pada anggota yayasan pundi rakyat. Pada pelaksanaan Pengabdian Masyarakat ini, dikarenakan masih pandemi Covid-19 dan harus mengikuti instruksi pemerintah agat tidak mengadakan kegiatan yang menyebabkan berkumpulnya massa dalam jumlah banyak, maka kegiatan ini dilakukan melalui secara online aplikasi Zoom Meeting.

Secara garis besar kegiatan pelaksanaan dilakukan dalam 4 (empat) tahap seperti pada Gambar 2 di bawah ini.

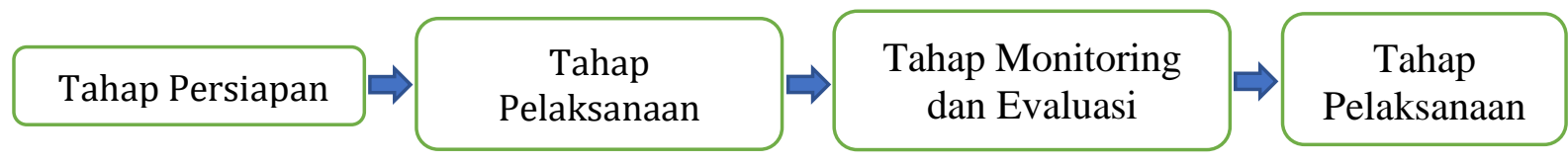

Gambar 2. Diagram Tahapan Kegiatan Pelaksanaan

Kegiatan Penyuluhan tentang Pemanfaatan Media Digital Marketing dalam Penyampaian Informasi sebagai Wujud Pelayanan Prima pada Anggota Yayasan Pundi Rakyat Jakarta Pusat dilaksanakan pada tanggal 23 Oktober 2021. Kegiatan Penyuluhan berjalan dengan lancar. Peserta penyuluhan dari Yayasan Pundi Rakyat terlihat antusias dengan materi yang diberikan. Hal ini terlihat dari awal hingga akhir acara, semua peserta mengikuti dengan baik. Kegiatan Pengabdian Masyarakat ini dapat berjalan dengan lancar. Hal ini disebabkan adanya faktor yang mendukung berjalannya kegitan pengabdian. Hal-hal yang mendukung berjalannya kegiatan pengabdian ini dapat diidentifikasi diantaranya antusisme para peserta. Faktor yang mendukung kegiatan adalah antusiasme peserta untuk memahami konsep media digital marketing, arti penting pelayanan prima, pentingnya peningkatan kualitas dan kuantitas karya profesi serta kemauan dari peserta pengabdian untuk mengetahui manfaat media digital marketing dalam penyampaian informasi untuk meningkatkan pelayanan prima

\section{HASIL DAN PEMBAHASAN}

Penelitian ini dilakukan pada Yayasan Pundi Rakyat sebagai mitra dari kegiatan pengabdian masyarakat, sehingga sebagai subjeknya yaitu anggota dari Yayasan Pundi Rakyat yang beralamat di di Jl. Taruna VIII No 6C RT. 004 RW 01 Kelurahan Serdang, Kecamatan Kemayoran Jakarta Pusat 10650. Tutor dapat dengan lancar menyampaikan materi mengenai media digital marketing apa saja yang dapat digunakan untuk dapat menyampaikan informasi untuk dapat dilakukan oleh para anggota Yayasan Pundi Rakyat seperti penggunaan blog, media social, berbagai bentuk email marketing, Pay-Per-Click Ads, dan sebagainya untuk dapat mewujudkan pelayanan yang prima pada masyarakat khususnya dengan para mitra dan juga donatur tetap bahkan mungkin juga calon donatur baru. Beberapa gambar dibawah ini adalah 
antusias dari peserta dalam mengikuti kegiatan pengabdian masyarakat serta pelaksanaan pada saat tutor menyampaikan atau memaparkan materinya.

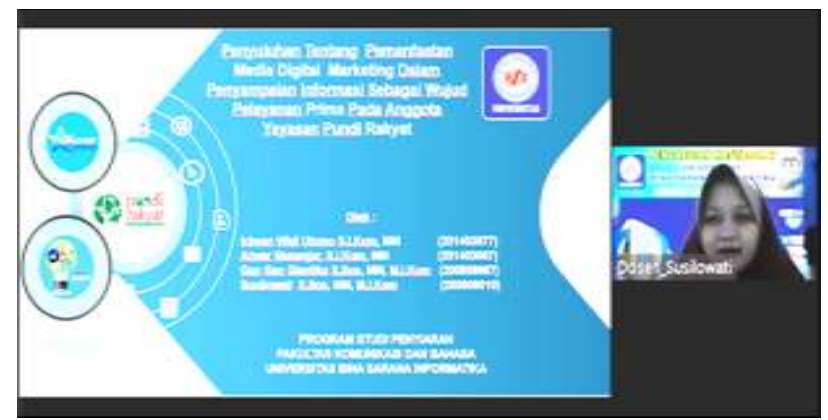

Gambar 3. Pelaksanaan pada saat tutor menyampaikan materi mengenai pemanfaatan media digital marketing sebagai media informasi sebagai wujud pelayanan prima

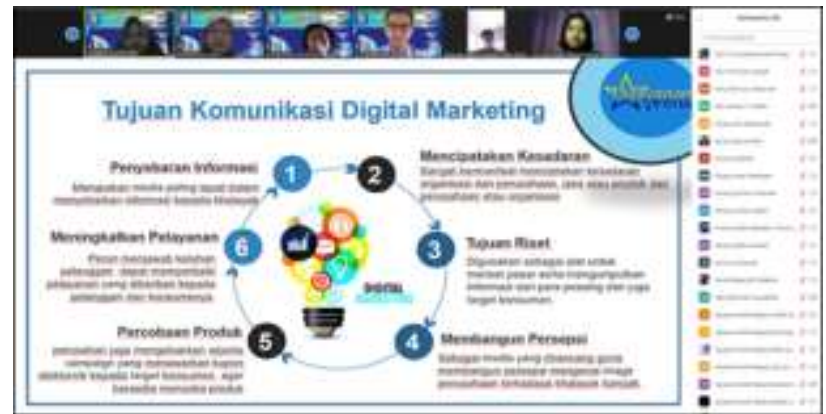

Gambar 4. Tutor sedang menyampaikan materi mengenai tujuan dalam komunikasi menggunakan media digital marketing

Pada pelaksanaan Kegiatan Pengabdian Masyarakat yang dilaksanakan dengan menggunakan video conference Zoom Cloud Meeting yang dihadiri oleh panitia pelaksana kegiatan dan juga para peserta dari anggota Yayasan Pundi Rakyat. Kegiatan penyuluhan tersebut dilakukan dengan memberikan paparan materi penyuluhan oleh tutor yaitu mengenai penggunaan media digital marketing dalam menyampaikan informasi kepada masyarakat akan kegiatan sebagai pemenuhan pelayanan prima. Seperti yang tampak pada Gambar 3 dan 4 adalah saat tutor menyampaikan materinya media apa saja yang dapat dipergunakan sebagai media digital marketing guna penyebaran informasi untuk para anggota Yayasan Pundi Rakyat.
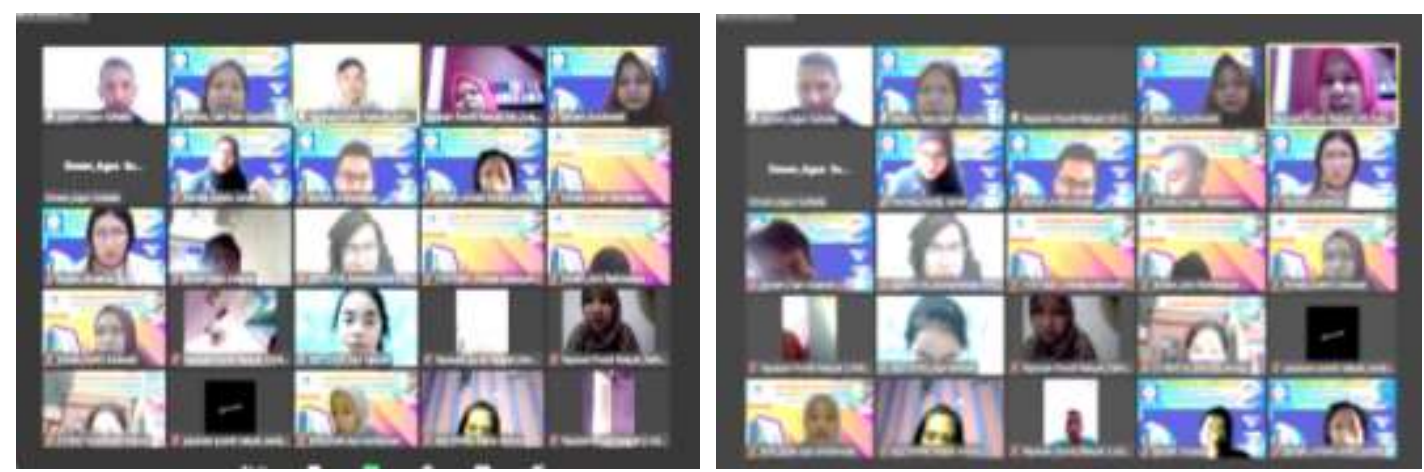

Gambar 5. Antusias dari peserta dari Anggota Yayasan Pundi Rakyat pada saat mengajukan pertanyaan pada tutor

Peserta antusias dan menaruh perhatian dalam mengikuti kegiatan yang berlangsung, yaitu dengan banyaknya pertanyaan yang diajukan, seperti salah satunya yang tampak pada gambar 5 dimana pertanyaan dan pandangan peserta akan penggunaan media yang tepat untuk mereka pergunakan dalam menyebarkan informasi untuk berbagai kegiatan yang dilakukan. 
Selain pengggunaan Media social marketing seperti Facebook dan Instagram yang telah mereka gunakan, maka dengan penyuluhan ini mereka tertarik untuk menggunakan blog dan juga content marketing.

Hasil dari pelaksanaan kegiatan Pengabdian Masyarakat ini pula sebagai outputnya selain penulisan jurnal pengabdian masyarakat pada jurnal abdi masyarakat / ABDIMAS dan juga press release yang dipublish pada BSINEWS dengan link https://news.bsi.ac.id/manfaatpenerapan-digital-marketing-untuk-peningkatan-pelayanan/.

\section{KESIMPULAN}

Pelaksanaan pengabdian masyarakat dengan anggota Yayasan Pundi Rakyat dapat dilaksanakan dengan berjalan lancar dan dapat dilakukan sesuai dengan rencana. Pelaksanaannya menggunakan media conference Zoom sebagai wujud kepatuhan dalam peraturan pemerintah untuk menerapkan pembatasan jarak fisik sebagai langkah preventif dalam mencegah penularan virus Corona. Pelaksanaan kegiatan pengabdian masyarakat merupakan edukasi dalam memberikan manfaat yang baik untuk anggota Yayasan Pundi Rakyat dan sesuai dengan apa yang dibutuhkan oleh mereka untuk melakukan penyebaran informasi msebagai wujud pelayanan yang prima dengan menggunakan memanfaatkan media digital marketing. Hal ini dapat dilihat dari antusias dari peserta yang melakukan interaktif dengan mengajukan beberapa pertanyaan dan pendapat mereka berkenaan dengan materi yang disampaikan oleh tutor.

Dalam segi materi dalam kegiatan pengabdian masyarakat yang disampaikan oleh tutor yaitu pemanfaatan dalam penggunaan media digital marketing dalam menyampaikan informasi sebagai bentuk pelayanan yang prima dapat berguna bagi anggota Yayasan Pundi Rakyat untuk dapat dimanfaatkan kedepannya oleh mereka dalam menyampaikan informasi semua kegiatan yang dilakukan oleh Yayasan Pundi Rakyat agar dapat diketahui oleh masyarakat atapun mitra mereka dalam penyumbang dana atau donatur dan juga calon dari para donatur baru.

\section{DAFTAR PUSTAKA}

Anggita, W., Yunita, A., Rosalina, E., \& Fahria, I. (2018). Persepsi Mahasiswa Terhadap Praktik Pengungkapan Sukarela dengan Non Profit Organizations Reporting Index di Universitas Bangka Belitung. Journal.Unsika, 3(2), 564-573. Retrieved from https://journal.unsika.ac.id/index.php/accounthink/article/download/1484/1209

Bakti.id. (2021). Mengenal Lebih Dekat Dengan 7 Media Promosi di Era Digital. Retrieved October 2, 2021, from https://bakti.id/ website: https://bakti.id/7-media-promosi-di-eradigital/

Barata, A. A. (2017). Dasar-dasar Pelayanan Prima (Xviii). Jakarta: PT Elex Media Komputindo.

Beon. (2016). 6 Jenis Email Marketing yang Dapat Digunakan untuk Bisnis Anda. Retrieved October 4, 2021, from https://beon.co.id/ website: https://beon.co.id/news/6-jenis-emailmarketing-yang-dapat-digunakan-untuk-bisnis-anda

Jakartaurbanhosting.com. (2019). Pemasaran Digital Organisasi Nirlaba (Yayasan/Donasi). Retrieved from JakartaUrbanHosting.Com website: https://jakartaurbanhosting.com/pemasaran-digital-organisasi-nirlaba/

Morisan. (2010). Manajemen Public Relations: Strategi Menjadi Humas Profesional. Jakarta: Prenada Media Group.

Niken, G. (2020). 7 Media Promosi Untuk Mendukung Bisnis di Era Digital - Ajaib. Retrieved October 2, 2021, from https://ajaib.co.id/ website: https://ajaib.co.id/7-media-promosiuntuk-mendukung-bisnis-di-era-digital/

Wisataone, V. (2018). Pelaksanaan Fungsi Hubungan Masyarakat Dan Publisitas Pada Organisasi Non-Profit. Jurnal Efisiensi - Kajian Ilmu Administrasi, XV(1), 15-27. Retrieved from https://journal.uny.ac.id/index.php/efisiensi/article/download/24482/12047 


\section{Halaman Ini Dikosongkan}

